Vol. 6, No. 1, 2020

Volodymyr Babyak ${ }^{1}$, Leonid Vozniuk ${ }^{2}$, Stanislav Bebko ${ }^{3}$

\title{
ARCHITECTURAL METHODS OF DESIGNING SPECIALIZED DWELLINGS FOR UNDERUTILIZED BLANK FACADES
}

\author{
${ }^{I}$ Assistant Lviv Polytechnic National University, Institute of Architecture and Design, Lviv \\ e-mail: volodymyr.babyak@gmail.com \\ orcid: 0000-0002-9672-0971 \\ ${ }^{2}$ Ph.D., assistant Lviv Polytechnic National University, Institute of Architecture and Design, Lviv \\ e-mail: vozniukleonid@gmail.com \\ orcid: 0000-0001-9512-8338 \\ ${ }^{3}$ Student of Lviv Polytechnic National University, Institute of Architecture and Design, Lviv \\ e-mail: Bebkostan@gmail.com \\ orcid: 0000-0002-6057-0027
}

Received: 01.04.2020 / Revised: 27.04.2020 / Accepted: 01.05.2020

(C) Babyak V., Vozniuk L., Bebko S., 2020

https://doi.org/10.23939/as2020.01.128

Abstract. The urban environment of developing cities requires more and more residential dwellings and workplaces. Expanding the city into the new, undeveloped territory is a tired and comprehensive method of expansion. In the existing framework of cities, there is an abundance of inefficiently used space in the guise of blank walls. London and Lviv are examples of cities which are guilty of this. Even though the two cities have developed their own architectural, cultural, economic, and social traditions, they still share the same potential to increase their density without sacrificing the comfort of their citizens. In the process of renovating existing developments, we have met with new possibilities of integrating new typologies, which can enrich the environment and city. This concept is a proposal for densifying the city using underutilized spaces while enrichening the environment.

Key words: Compact dwellings, renovation of residential blocks, dwelling unit.

\section{Problem statement}

London has a housing crisis. Prices for flats are increasing indefinitely and disproportionally to the quality of housing, and the working-to-middle socio-economic classes are migrating far away from the cities they want to live in. Additionally, for humanity to minimize its impact on the environment, we need to maximize the functionality of our existing developments.

\section{Analysis of recent research and publications}

The direction of architecture is heading towards the humanization of urban environments. This article is based on information from architectural and urban environment design guides published by the London's city council; CABE's (Commission for Architecture and Built Environment) design guides, as well as the work of various architects and the analysis of their architectural solutions.

\section{Objective of the article}

The objective of the article is a solution which helps regain and utilize the lost potential of blank facades; an improvement of population density without either added allotment of territory or sacrificing the comfort of existing inhabitants; an optimal combination of functional zones and spaces in residential dwellings. 


\section{Results and discussions}

Today London is one of the world's' wealthiest and most influential cities in the world. For such a city as London, it has an impressive amount of wasted potential in the guise of blank facades (Fig. 1). These blank facades break the rhythm of the surrounding architecture and do not contribute anything beneficial to the city. At most, they are converted to advertisement billboards or left alone, as is shown here.

The optimization of these facades is a good idea for several reasons: new dwellings will emerge in the heart of the city; commuting to work will be shortened; increased amount of vegetation; increased communication between socio-economic classes; and, the last but not the least, it will not negatively influence the existing environment. To the contrary, it will enrich it.

The main categories of dwellings in London are terraced housing and low-rise apartments (Fig. 2) [1]. Typical blocks of terraced housing are fairly inconsiderate to their surroundings, and in turn, do not fully utilize the potential the site has to offer. For example, if one were to take a walk through Colville terrace in London, he/she would notice 10 staggeringly huge blank facades, which face a reasonably quiet street. On this street only, it is possible to construct at least another 30 brand-new dwelling units, without any additional allotment of territory and sacrificing the comfort of existing inhabitants of Colville terrace.

Lviv has a similar problem (Fig. 3). Walking through Lviv, you would see dozens of huge blank facades. They are not only located on side streets and alleyways of the centre, but they are also found on main streets such as Volodymyr Velykyi street, Zelena street, Lychakivska street, etc.

Blank facades such as these should not be dismissed. They negatively influence the atmosphere of their surroundings and are usually adapted for use of advertisement billboards, which disharmoniously populate and break the rhythm of the surrounding architecture and the city's atmosphere. At the Fig. 3 you can see a wonderful restaurant of authentic Georgian cuisine, but no one would be able to recognise that from the appearance of the façade.

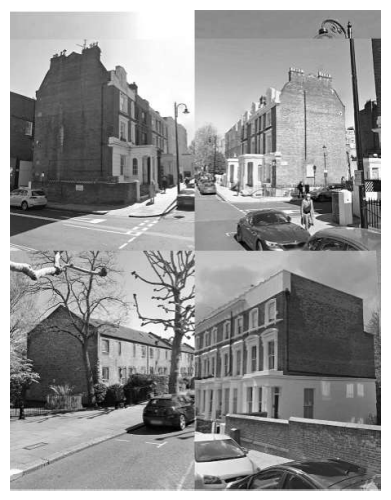

Fig. 1. Unused blank facades in London [Google Earth]

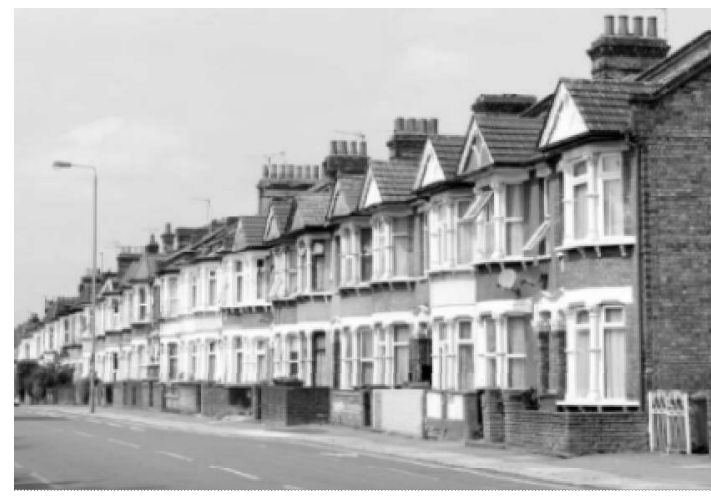

Fig. 2. Terraced housing [blogsavill.com]

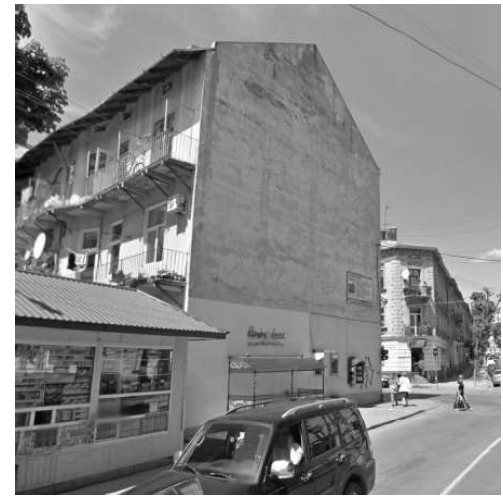

Fig. 3. Huge blank façade in Lviv [Google Earth]

Instead of hanging billboards or commissioning artists to cover up these eyesores, it's possible to implement well-designed, high-quality micro-dwelling units. These would enrich the architectural diversity and increase the amount of vegetation in a city. These blank facades should be seen as potential locales of highquality dwellings in excellent, central parts of cities.

This concept comprises of prefabricated dwelling units mounted on steel columns which are attached to the blank walls of existing buildings. These dwelling units are not constrained for use only on blank facades, they are capable of being stacked upon each other, forming a low-rise apartment complex. A couple of different variants of dwelling units have been devised (Fig. 4, $a, b, c$ ), each designed to accommodate a specific tenure:

1. A one-story dwelling unit with a mezzanine, designed for young couples without children $\left(29.33 \mathrm{~m}^{2}\right)$ (a).

2. A one-story dwelling for old generations and their families $\left(60.73 \mathrm{~m}^{2}\right.$.) (b).

3. A two-story dwelling unit for a young family with a child $\left(42.42 \mathrm{~m}^{2}\right)(\mathrm{c})$.

Not every environment is suitable for dwellings. These units are capable of being converted to into miniature offices (Fig. 5) in environments where conditions are not optimal for living, such as a busy street or where the host blank wall is facing train tracks. (Fig. 6) 


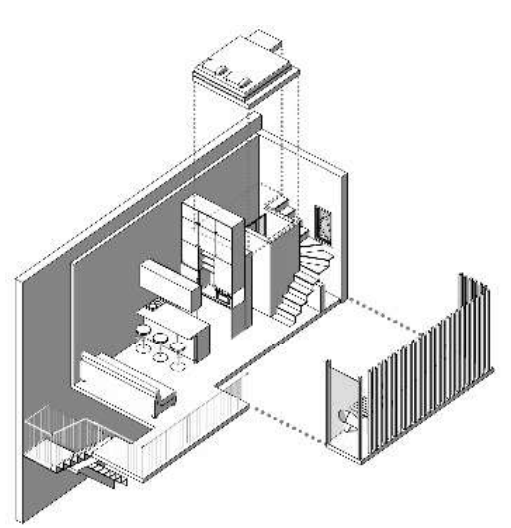

a

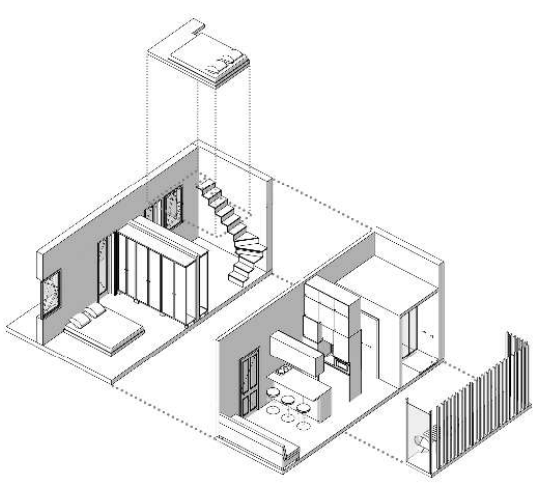

$\mathrm{b}$

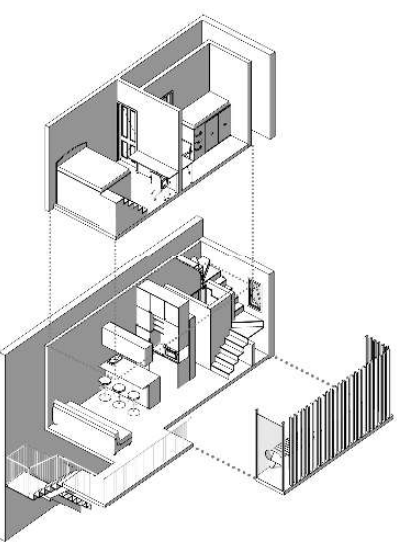

c

Fig. 4. Variants of dwelling unit floor plans. a, b, c. Created by the author

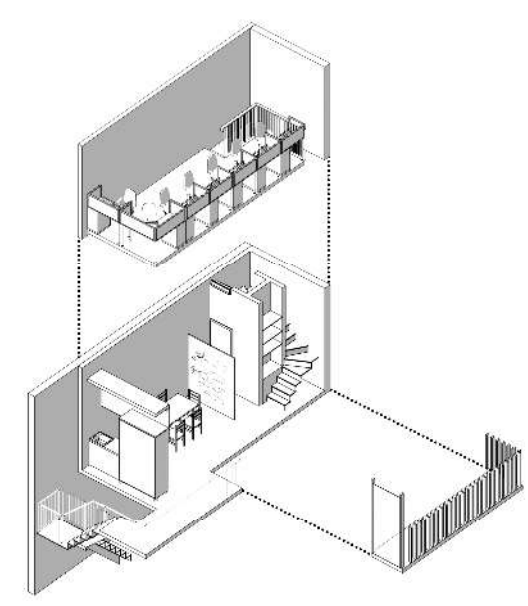

Fig. 5. Design solution for a compact office. Created by the author

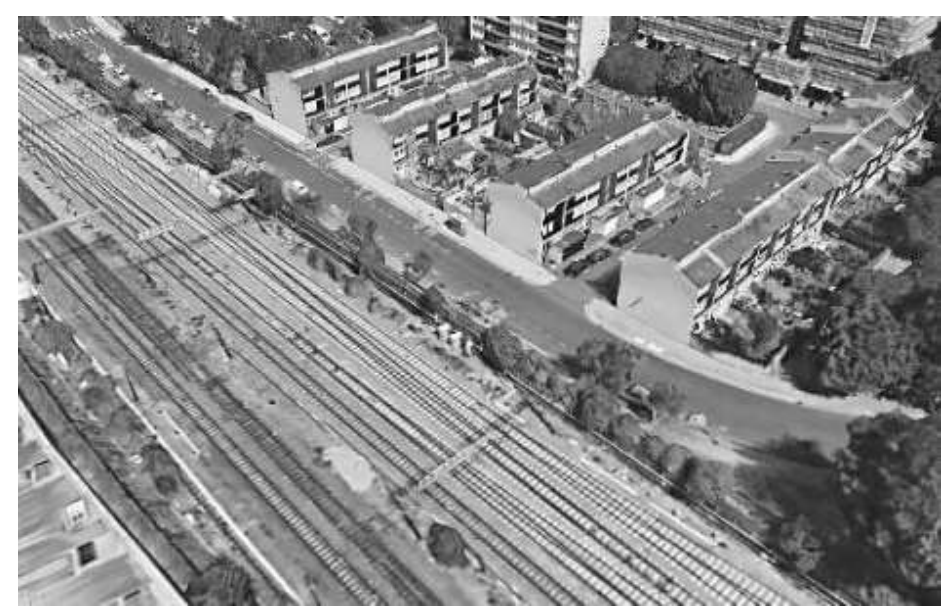

Fig. 6. Train tracks, North Kensington,London [Google Earth]

These dwelling units will be constructed in specialized warehouses and be transported to the site when the host wall is ready to receive them. They are small enough to be transported using trucks and will be elevated to the necessary position using a crane and be mounted to the steel columns. The prefabrication of dwelling units allows for lower tolerances and higher-quality enveloping of the buildings, resulting in higher energy efficiency systems while reducing time for construction [6].

The first story of all dwelling units has a height of $3.4 \mathrm{~m}$. A high ceiling provides the opportunity to implement a mezzanine in the space and use it as a foundation platform or storage space.

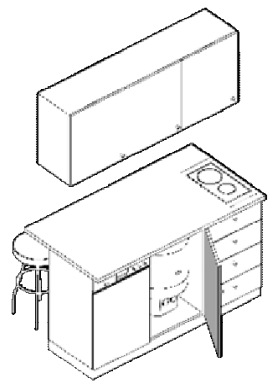

Fig. 7. Functional kitchen cabinetry. Created by the author

Additionally, studies show that higher ceilings are correlated with improved cognitive performance tests and better mood [2].

The second story has a minimum floor-to-ceiling height of $2.5 \mathrm{~m}$. This results in a lighter structure, conserves resources and influences the inhabitants to not lock themselves up in their private quarters, but rather spend time in common areas. It is still a comfortable ceiling height.

For micro-dwelling units' internal volumes to optimally function, it needs furniture which is designed specifically for the space it occupies. Therefore, the kitchen isn't merely a workspace with a cooktop (Fig. 7). Since the countertop is $90 \mathrm{~cm}$ deep, it provides space for other types of work as well. Additionally, it also houses a table for 5 and standard kitchen equipment such as a dishwashing machine, an electric water heater, and storage for various kitchen tools. 

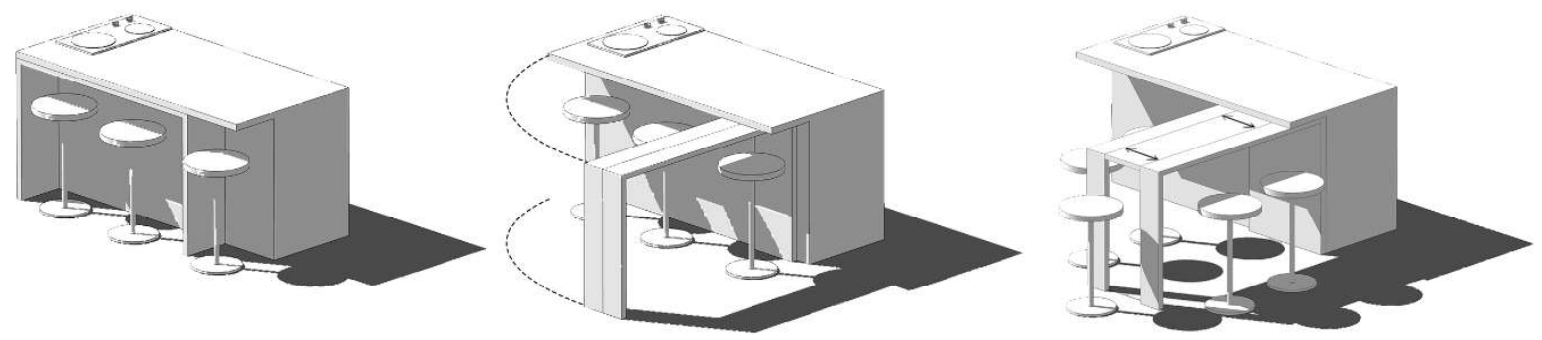

Fig. 8. Multi-functional kitchen cabinetry. Created by the author

The kitchen's floor-to-ceiling cabinet contains the kitchen and household equipment (refrigerator, sink, laundry, electric oven), and houses storage for cooking equipment, dishes, and a pantry (Fig. 9). The opposite side houses a standard wardrobe where residents can hang their clothes and store their shoes. This floor-toceiling cabinet/wardrobe, from the mezzanine up, contains storage for books, cellphones, lamps, décor, etc., to enjoy relaxing on the bed. (Fig. 9).

Here is an interesting and creative storage solution (Fig. 10). Ample amounts of storage are found inside of the bed frame, which houses a full-sized wardrobe, and a couch and table on wheels. In this manner, the architect solved the problem which small spaces. "We put everything which isn't the kitchen or bathroom under the bed" [5].

Taking this type of functional design as an example, the bed frames in the two-story dwelling units also house 2 full-size wardrobes, as well as 6 shelves, and storage compartments inside the steps of the stairs.
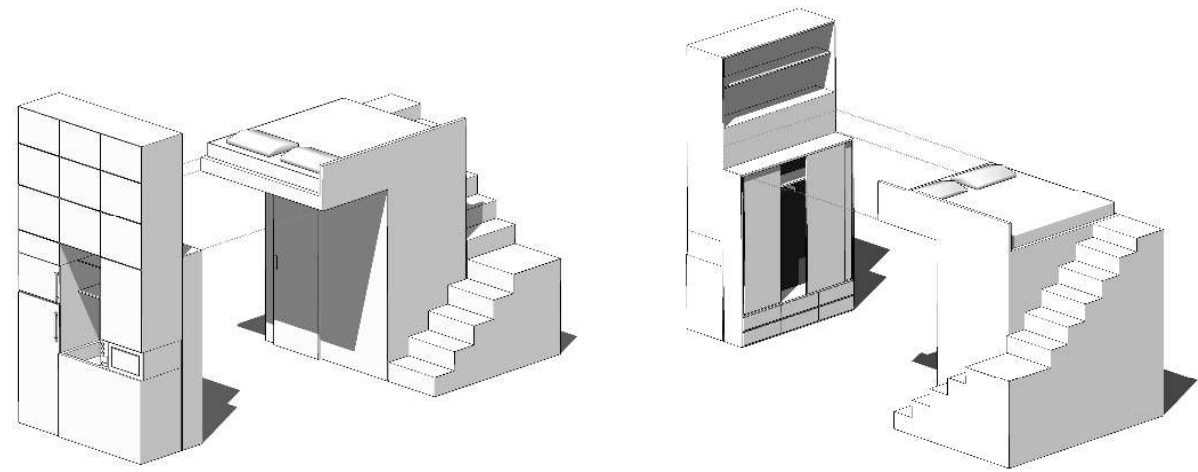

Fig. 9. Floor-to-ceiling kitchenette/wardrobe. Created by the author

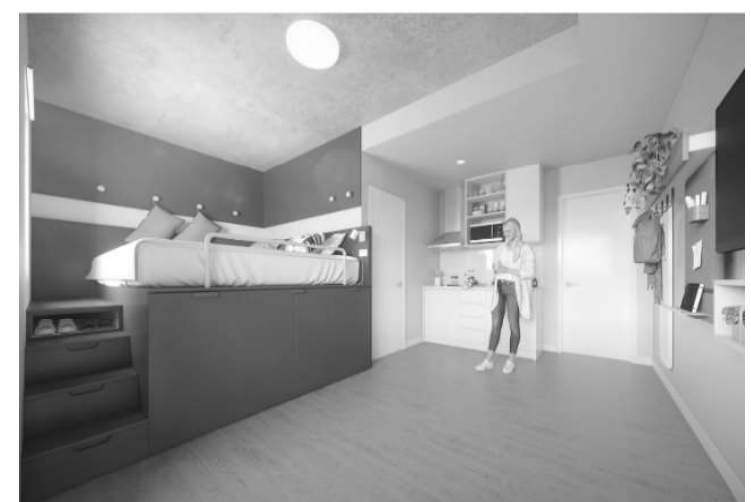

Fig. 10. Micro-dwelling unit. Never Too Small [4]

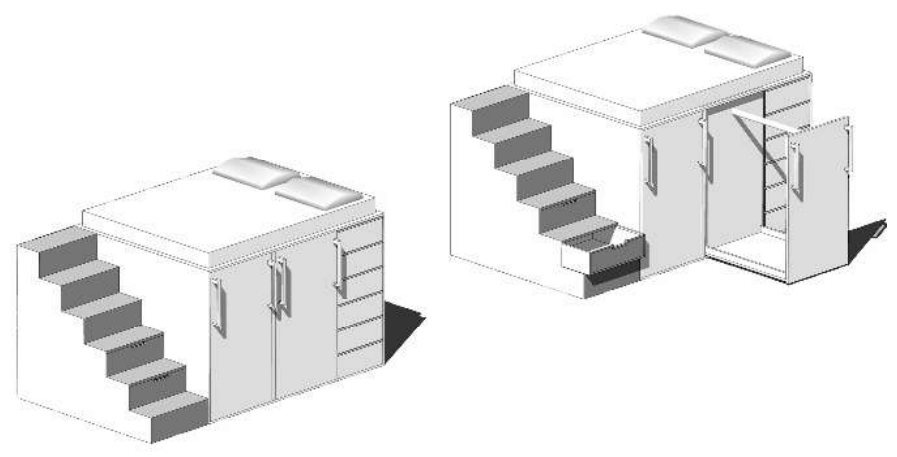

Fig. 11. Bed/wardrobe. Created by the author

This type of furniture exists and is used in interior design projects where every square meter must be planned in the best, most efficient possible way. Furniture like this is custom-made to fulfil the requirements of both compactness and comfort.

These dwelling units are best suited for central regions of cities, or where there is well-developed public transportation infrastructure. It will be easy for the residents to get to work, visit grocery stores, and go out and 
enjoy the city. Since the dwellings are fairly small, the residents should not feel trapped and unable to go outside and do something. These units are not suitable for the countryside or outskirts of the city.

These dwelling units are not necessarily constrained to being positioned on blank facades - they can also be stacked on top of one another and form a low-rise residential complex. For blocks which face N/S, dual aspect units will be primarily used. For blocks which face E/W, single aspect units will be the primary type of unit used. This will help to ensure the dwelling units receive the appropriate amount of insolation, as well as ensuring a healthy balance of a mixed-tenure population.

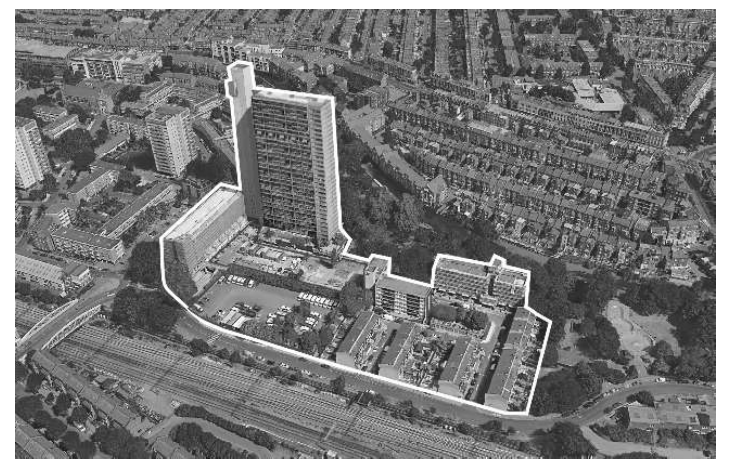

Fig. 12. Existing site. [Google Earth]

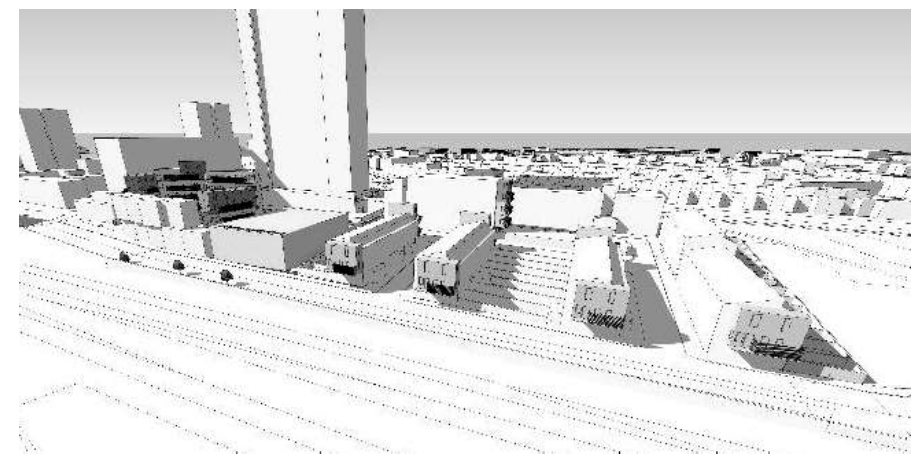

Fig. 13. Redevelopment proposition. Created by the author

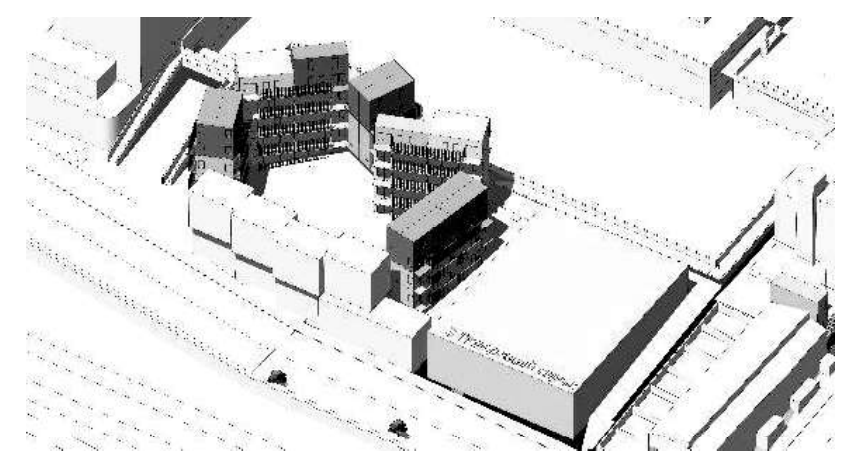

Fig. 14. Redevelopment proposition.

Residential complex. Created by the author

This specific project is based in North Kensington, London W10 (Fig. 12). This site was developed in the early 1970s based on a project designed by the architect Ernő Goldfinger. Today the condition of the site is unsatisfactory. There are many areas which are "no mans' land" (no one has responsibility for it, no one uses it); the streets and sidewalks are dominated by the automobile (even the sidewalks are paved); some areas lack passive surveillance; some areas have simply been abandoned, where there could (and should) be playing fields and playgrounds; there's a huge private parking lot; there's a lot of blank facades.

Here we can see how this concept can be applied to a territory (Fig. 13). The dwellings and offices cantilever out from existing residential terraced housing at a height of $3.5 \mathrm{~m}$ from the sidewalk, which is more than enough to allow for most types of transport to drive and park underneath it, as well as not being a bother to pedestrian traffic.

Part of the territory is allocated to a low-rise residential complex (Fig. 14) This type of complex is fairly secure, due to the blocks having exterior corridor entryways and windows in non-private rooms open to walkways and staircases. It is immediately visible if an "outsider" is visiting the complex. This type of surveillance is called "passive surveillance" and is an important part of security in neighbourhoods [4].

There are several points which are absolutely necessary for a residential complex, or neighbourhood, to function well and be a place people can call "home" [3].

1. Characteristic and unique architecture

2. High-quality architecture

3. Pedestrian priority over automobiles 
4. Abundance of passive surveillance

5. Accessibility to public transport

6. Mixed-tenure population

7. Communal grounds.

\section{Conclusion}

Architects have a responsibility to utilize all the potential a site has to offer. The concept of redeveloping unused blank facades is one solution of tapping into lost/overlooked potential of the urban environment. Using the site in North Kensington, London as an example, it's apparent how we can redevelop and transform the existing site into a place people are proud of. A place of high-quality architecture, where there are playgrounds instead of an asphalt lot, and where the people are prioritized over the automobile. In this case, the population density would be increased, and office jobs would be created. The creation of new subcategories of dwellings and workspaces would minimize intercity migration and add liveliness to an existing suburban environment. As time passes and the urban landscape evolves, it is important for architects to devise possible paths and solutions to ever-changing problems.

\section{References}

Atkin J. 2017. What type of housing do people live in? [online]. Joanne Atkin. Mortgage Finance Gazette. Available at: https://www.mortgagefinancegazette.com/market-news/housing/type-housing-people-live-11-08-2017/.

Ceiling Height Can Affect How A Person Thinks, Feels And Acts. 2007. [online]. University of Minnesota. ScienceDaily. Available at: https://www.sciencedaily.com/releases/2007/04/070424155539.htm.

Designing Great Places to Live / D.Birkbeck, S. Kruczkowski, P. Collins, B. Quinn. - London: Building for life, 2007. 24 c. - (Nottingham Trent University: CADBE for the Building for Life Partnership).

London Housing Design Guide - London: Design for London August 2010 Published by London Development Agency, 2010. - 108 c. - (Mayor of London). - (Design for London).

NEVER TOO SMALL ep 29 19sqm Micro Apartment \& Co Living Space - UKO [online]. NEVER TOO SMALL. - 2019. Available at: https://www.youtube.com/watch?v=eHTTmlv-TLU\&t=224s.

Ryan S. E. Prefab Architecture: A Guide to Modular Design and Construction / Smith E. Ryan., 2011. - 384 c. - (John Wiley \& Sons).

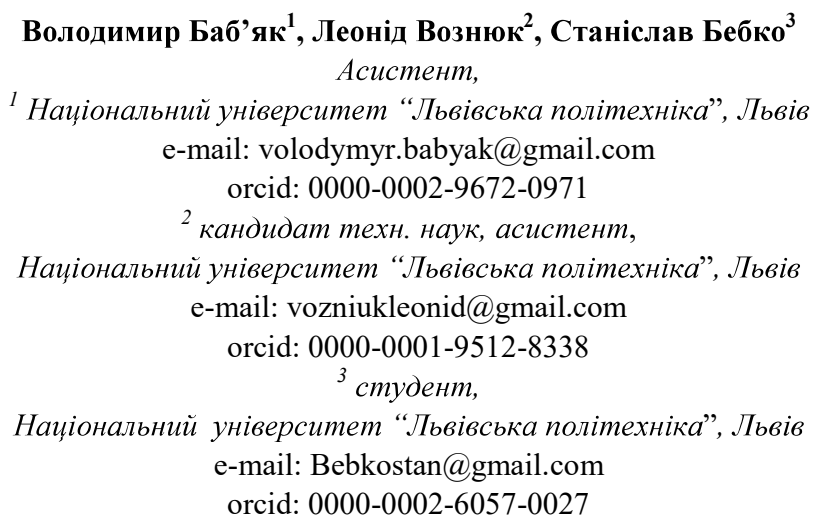

\section{АРХІТЕКТУРНІ ЗАСОБИ РЕАЛІЗАЦІЇ СПЕЦІАЛІЗОВАНОГО ЖИТЛА В МЕЖАХ НЕЕКСПЛУАТОВАНИХ ГЛУХИХ ТОРЦІВ}

\footnotetext{
Анотація. Урбанізоване середовище міст, які розвиваються, потребує все нових та нових житлових площ та місиь для прикладання праиі. Розширення міста за рахунок нових територій є затратним $і$ екстенсивним шляхом розвитку. У тканині міст є занадто багато неефективно використаної площуі у вигляді глухих ториів. Прикладами невикористання таких ториів є історичні міста, як-от Лондон та Львів. Хоча иі два міста є прикладами реалізаиій різних архітектурних, культурних, економічних, соціальних традиџій, перед ними постала можливість спільного вирішення ущільнення існуючої забудови. Поруч із функиією ущільнення забудови, важливою є необхідність подолання
} 
асочіальних явищ в незадіяних містом закутках. У ході реноваиії старої забудови відкриваються нові можливості з інтеграчї нових утворень, що збагатять середовище та місто. Конџепџія полягає в гуманізації глухих ториів $i$ повернення людського масштабу урбанізованим просторам міст, не забираючи площі від міста.

В Лондоні є житлова криза. Ціни на квартири нескінченно зростають, якість житла падає, $і$ нижчий-середній економічний клас людей переселяються щуодальше від міста, де хочуть жити. До того, щуоб людство мінімізувало свій вплив на навколишне середовище, нам потрібно максимізувати користь і ефективність нашої існуючої забудови.

Архітектор має відповідальність використовувати весь потенціал середовища, в якому він/вона проєктує. Використання екстенсивних засобів розвитку приводить до кінцевого збільшення затрат та неефективності в майбутньому. Концепџія використання незадіяних ториів $\epsilon$ одним із варіантів розв'язання проблеми неефективно використаної площі та повернення/використання потенціалу середовища в місті. На прикладі ділянки в Лондоні показано можливість перепланування і перетворення на високоякісну та иікаву територію, з дитячими майданчиками замість асфальтованого подвір'я, з вуличками, де перевагу віддають пішоходові, а не автомобілю. Як результат - у иій забудові збільшено щільність населення та надано можливість із розгортання офісних робочих місиь поблизу дому. Наповнення існуючої житлової забудови місчяям прачі та новими типами субжитла зменшує маятникову міграцію в місті та додає життя спальним районам та субурбії. Нові часи дають нові виклики, і архітектори повинні показувати можливі иляхи розв'язання існуючих проблем.

Ключові слова: компактне житло, реновачія житлової забудови, житлова одиниия. 